S. Terepyshchyi ${ }^{1}$, Dr. Sc. (Philos.), Assoc. Prof., orcid.org/0000-0001-5506-0914,

D. Svyrydenko ${ }^{1}$, Dr. Sc. (Philos.), Assoc. Prof., orcid.org/0000-0001-6126-1747,

K. Zakharenko ${ }^{1}$, Cand. Sc. (Polit.), orcid.org/0000-0003-0980-7313,

K. Bezgin'2 , Dr. Sc. (Econ.), Assoc. Prof., orcid.org/0000-0003-2077-8023,

O. Kulga ${ }^{3}$, Cand. Sc. (Econ.), Assoc. Prof., orcid.org/0000-0003-1476-7299

\title{
EVALUATION OF DONBAS UNIVERSITIES' ECONOMIC POTENTIAL: PROBLEMS OF PERSONNEL TRAINING AND UNEMPLOYMENT
}

Purpose. The research is aimed at assessing the level of satisfaction of employers of Donbas with the existing training system and the conceptualization of a set of qualities that a graduate must possess in order to ensure unhindered free competition in the labor market in the mining region.

Methodology. A quantitative study envisaged conducting an electronic sociological survey of two groups of respondents - employers and graduate students of the universities of the region. The survey covered enterprises located in all controlled cities of Donetsk and Luhansk regions. The total survey covered 93 enterprises. The authors used an adapted marketing technique ServQual, in which each employer was required to determine the rating units according to the competent criteria. The main purpose of the survey of university graduates was to assess the effectiveness of the implementation of the existing system of higher education in the region and the level of satisfaction with the educational and professional expectations of graduate students. The total number of respondents was 961 persons.

Findings. The conducted research made it possible to identify the main problems existing in the field of training in the universities of the region as well as to assess the level of satisfaction of employers and students with the quality of the acquired knowledge, skills and abilities, to define the most critical competences that are the least developed among graduates. As a result, we assessed the current state and prospects for expanding cooperation between business and educational institutions, the effectiveness of career centers at universities and the level of additional services provided by universities in the field of employment.

Originality. The list of conceptual recommendations for improving the economic potential of Donbas universities has been formed in particular through improving the mechanisms of employment of graduates. The differences in the perceptions of educational institutions in the region about the results of their own activities and existing needs, which are presented in a specific combination of knowledge, skills and skills expected by regional employers, are revealed. These differences recorded in the comprehensive study of key stakeholders in the educational process of the region are the result of, on the one hand, a low the adaptability of universities, which is due to existing norms, strictly regulating the activities of universities, and, on the other hand, the rigidity of universities to the reengineering procedures in the constant self-improvement of their own activities.

Practical value. The ways of correction of the competence profile of the university in the mining regions are shown on the basis of more flexible curricula adapted to the needs of the real sector of the region's economy. The structure of such plans should consist of two components: a stable core and a flexible (custom) periphery. This will allow providing the added value for the offered educational services oriented on customization and diversification.

Keyword: economic potential, personnel training, unemployment, Donbas, miming region, modern university

Introduction. The current situation at the Donbas labor market can be defined as critical. Changes in the structure of demand and supply that have arisen in the military conflict background have caused an exacerbation of the existing problems and the emergence of new ones that have not been known in management practice before. One of these problems lies in an insufficient level of satisfying employers' needs by the personnel, which is largely due to the following factors: the ineffectiveness of the youth professional self-determination; the lack of systematic information as for professions in demand at the labor market; low level of interaction between employers and the educational sphere, the imperfection of the existing educational system, the quality of students' training decrease due to the growth of the number of private higher education institutions, etc. The poor quality of young specialist training, reduce the return on investment in human capital and hinder the development of the economy.

The solution of the youth unemployment problem lies in the cooperation between educational institutions and employers. The creation of Career Development Centers in the regional universities is one of the variants of such interaction.

(C) Terepyshchyi S., Svyrydenko D., Zakharenko K., Bezgin K., Kulga O., 2019
The main goal of the research is to assess the current and future potential of the Donbas universities in terms of their place and role in preparing competitive skilled workforce, the realization of employment opportunities. To achieve the goal, the statistical and sociological methods were used in the research. The statistical research involved carrying out the assessment of the labor market development level in the region, determining the existing level of pressure on it and the structure of the supply-demand ratio. In addition, the statistical survey included an assessment of the market development level for educational services in the region, assessment of the training structure and rankings of the Donbas universities. The sociological study included carrying out a quantitative survey (interviewing students and employers in the region on the basis of pre-created and approved questionnaires using the Google-form tool) and a qualitative survey that included focus group interviews among student activists and university leaders and university professors in the region, and also conducting in-depth interviews among the key employers taking into account the "Top200 Ukraine 2018" rating [1]. According to experts' vision, 13 of regional universities should be listed at rating (Table).

According to the information-analytical portal on higher education in Ukraine, there were 661 higher educational institutions including 29 in Donetsk region and 13 in Luhansk re- 
Universities of Donetsk and Luhansk regions which are included in the "Top 200 Ukraine 2018" rating

\begin{tabular}{|c|c|c|c|c|c|c|c|}
\hline \multirow{2}{*}{ Universities } & \multirow{2}{*}{$\begin{array}{c}\text { Assessment } \\
\text { of the integral activity } \\
\text { indicator in } 2018\end{array}$} & \multicolumn{6}{|c|}{ Rating } \\
\hline & & 2018 & 2017 & 2016 & 2015 & 2014 & 2013 \\
\hline Vasyl Stus Donetsk National University & 31.51 & 27 & 27 & 32 & 25 & 20 & 17 \\
\hline Donetsk National Technical University & 30.01 & 34 & 25 & 23 & 20 & 16 & 18 \\
\hline Volodymyr Dahl East Ukrainian National University & 26.31 & 50 & 41 & 37 & 34 & 27 & 30 \\
\hline Donbas State Engineering Academy & 23.69 & 70 & 71 & 71 & 71 & 72 & 72 \\
\hline Luhansk Taras Shevchenko National University & 23.68 & 71 & 64 & 49 & 33 & 25 & 21 \\
\hline $\begin{array}{l}\text { Donetsk National University of Economics and Trade named after } \\
\text { Mykhailo Tugan-Baranovsky }\end{array}$ & 22.45 & 87 & 74 & 61 & 58 & 52 & 57 \\
\hline Donetsk National Medical University & 21.22 & 96 & 85 & 65 & 30 & 23 & 23 \\
\hline Donetsk State University of Management & 20.39 & 114 & 112 & 94 & 66 & 64 & 64 \\
\hline Luhansk State Medical University & 16.96 & 153 & 154 & 145 & 67 & 61 & 60 \\
\hline Luhansk National Agrarian University & 16.25 & 162 & 162 & 153 & 123 & 118 & 90 \\
\hline Donbas State Pedagogical University & 15.66 & 167 & 163 & 163 & 159 & 166 & 167 \\
\hline Donbas National Academy of Civil Engineering and Architecture & 15.10 & 172 & 173 & 172 & 169 & 151 & 164 \\
\hline Donetsk Law Institute of Ministry of Internal Affairs of Ukraine & 12.49 & 189 & - & - & - & - & - \\
\hline
\end{tabular}

gion at the beginning of 2017-2018 academic year in Ukraine [2]. As a result of the antiterrorist operation in Donetsk and Luhansk regions, 17 universities were displaced from the occupied territories, three of them (Donetsk National University, Luhansk State Academy of Culture and Arts and Luhansk National Agrarian University) left Donetsk and Luhansk regions. Fourteen internally displaced institutions have found refuge within the region. [3].The total number of students in Donetsk region is 32.1 thousand people, and in Luhansk region it is 19.1 thousand people (as of 2017/2018 academic year), including 29.9 thousand people studying at the displaced higher educational institutions, which is $20 \%$ less than in 2014/2015 [3].

There were 8.8 thousand of graduates from educational institutions of Donetsk region in the 2017/2018 academic year and 5.3 thousand of graduates were in Luhansk region. The total number of graduates of Donbas Universities is 14.1 thousand. The displaced universities of Donetsk and Luhansk region graduated 8797 people (with the exception of medical schools that did not provide statistical information), that is, about two thirds of all graduates of the region.

Literature review. The conceptual design of the study was preceded by an acquaintance with the large-scale research by A. Valero and J. Van Reenen [4]. The authors show the relationship between GDP per capita and universities on the sample of more than 15000 universities in 78 countries: the GDP has grown correspondingly the increased human capital supply and increased innovation. But, this study does not address the conflict and post-conflict regions and the impact of universities on post-war reconstruction.

There are many case studies on the research of local conflicts. For example, J. Barbara and L. Walsh explore the potential of universities as important actors in post-conflict societies as illustrated by the National University of Solomon Islands [5]. But, this study sheds weak light on the Ukrainian situation directly.

Another interesting study is the article by C.J.Santos, J.Solano and S. Nieves, who analyze the Autonomous University of the Caribbean Basin. This university supports the national policy of dialogue and peace building in Colombia. The university created the "Department of Peace". This is an interesting description, obtained through a survey of $281 \mathrm{stu}-$ dents studying the subject "Society and Culture for Peace" [6]. We see that student surveys are an important source of information and will use this approach in our study.
The conduct of this study was preceded by our appeal to the problems of economic development of mining regions [7]. The methodological framework of the study was facilitated by a series of studies by K. Wach, a well-known researcher on the economic problems of Polish universities [8, 9]. An appeal to the competent problems of modern students updated the work of S. Rudenko [10], O. Bazaluk [11]. In recent years, the conceptual explication of institutional challenges for modern Ukrainian universities has been proposed by W. Mozgin [12] and O. Kyvliuk [13]. The peculiarities of university reform in the light of economic challenges were investigated by A. Oleksiyenko [14].

Despite the series of publications, they do not fully cover the problem of matching the system of training specialists on the territory of the conflict affected Donbas to the demands of the labor market as well as the real sector of the economy requests. These studies do not use qualitative and quantitative research, or concentrate on a different region or time spans.

Methods. At the end of 2018, the quantitative and qualitative research aimed at the defining key problems and perspectives of Donbas labor market was conducted under the sponsorship of Czech organization "People in Need" [15]. The authors of the article were also involved into the mentioned survey.

The authors will concentrate our attention on the quantitative study, the main purpose of which was to identify the problems of the labor market in the Donbas and the prospects for increasing the available employment opportunities for university graduates in the region. The adapted marketing technique, ServQual, was used for which each employer had to determine the following assessment units according to the competent criteria. The "Expectations" block defines the views of employers on how they would like to see an ideal young specialist, the level of his/her knowledge, skills and skills acquired during his/her studies at a higher education institution. The purpose of the "Perception" block is to identify employers' thoughts about the level of knowledge and skills of a modern graduate. The "Importance" block is intended to assess the importance of certain knowledge, skills and abilities in the work of a specialist with higher education. The estimation method involves calculating the quality coefficient, which has a mathematical expression

$$
Q_{i}=P_{i}-E_{i},
$$


where $Q_{i}$ is the coefficient of quality by ${ }^{i-m}$ criterion; $P_{i}$ is consumer perception of quality according to the ${ }^{i-m}$ criterion; $E_{i}$ is consumer expectation of quality according to the ${ }^{i-m}$ criterion.

In this case, the negative quality coefficients that are as close as possible to zero value are considered satisfactory. The positive value of the coefficients indicates good quality. A similar technique was used when interviewing students (graduates); for them the essence of the blocks "Expectation", "Perception" and "Importance" was expressed in the following: the "Expectations" block was intended to determine the expectations of the specialist regarding the adequacy of the level of knowledge acquired during the training of student's skills. The "Perception" block assesses the compliance of the presented criteria with the expert's current level of knowledge, skills and abilities. The "Importance" block allows you to determine the extent to which certain knowledge, skills and abilities are affected by the work process. The criteria and orientations for assessing employers and graduates were identical, which made it possible to compare existing perceptions of employers and specialists with regard to the competences required for work and assess the perceptions of the quality of educational services by the two main consumers (citizens and enterprises).

Results. As a result of the conducted research, the collected data was grouped into the report. According to the results of the research on the correspondence of the level of skills and knowledge of modern young specialists with the views of employers on the "ideal" graduate, it is determined that by twenty two quality criteria defined they are characterized by negative values of the coefficient of quality, ranging from -0.41 to -1.23 . That is, there is a rather high degree of dissatisfaction with the requirements of employers by young professionals.

The highest quality ratios were obtained according to the following criteria: computer skills $\left(Q_{i}=-0.41\right)$; knowledge of a foreign language $\left(Q_{i}=-0.65\right)$ and leadership qualities $\left(Q_{i}=\right.$ $=-0.76$ ). The smallest coefficients of quality have (that is, the most inappropriate) criteria: knowledge of specialized applied programs necessary for professional activity $\left(Q_{i}=-1.23\right)$; knowledge of the legislative and normative base in the field of professional activity $\left(Q_{i}=-1.2\right)$; possession of the skills of collecting, processing, analyzing, summarizing information and presenting the results $\left(Q_{i}=1.16\right)$ and the ability to cope with new and unforeseen situations $\left(Q_{i}=1.07\right)$.

However, the most representative quality analysis and identification of existing problems is the ratio of the quality factor of the criterion and the importance of this criterion in the professional activity of a specialist. Graphically, this ratio is shown in Figure.

Quadrant 1, which contains criteria that are of a high degree of importance and relatively high with other levels of their quality and because of this are the most successful in the current state, includes:

1) the ability to work on a computer, this skill was recognized by employers as one of the key characteristics required in the activities of a modern specialist in economic education (the assessment of importance is equal to 4.6), in addition, it has the best quality factor $\left(Q_{i}=-0.72\right)$;

2) discipline ranks seventh in the ranking of the importance of the criteria with an estimate of 4.42 and a coefficient of quality -0.82

3) creative potential ranks fifth among the key characteristics of a modern young specialist and has a fairly high level of significance of 4.35 and a coefficient of assessment with a value $\left(Q_{i}=-0.83\right)$;

4) the ability to take initiative in professional activities has almost the marginal significance of moving one to two and three to the quadrant, and therefore falls into the critical area that needs some kind of educational intervention. The importance of this criterion is 4.34 , and the coefficient of quality $Q_{i}=-0.83$.

In general, all the Quadrant 1 criteria are positive in terms of meeting the needs of employers, but there are some reserves for their development, since the degree of deviation of the quality of graduates from the benchmark is rather high. In addition, there are criteria found in the problem transition zone, which makes it necessary to pay more attention to them.

Quadrant 2, which includes criteria that are characterized by a low value of an indicator of importance and a low quality

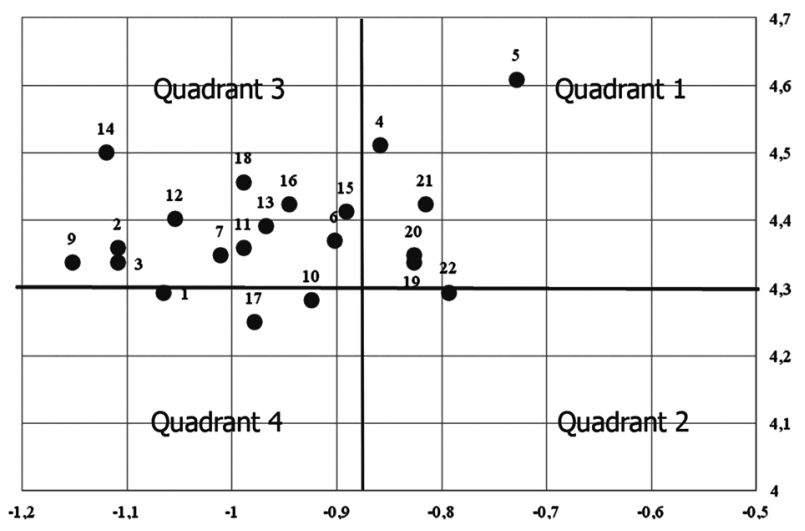

$1-$ General theoretical training by the profile

2 - Ability to perform basic professional functions by profile

3 - Ability to apply the acquired theoretical knowledge in professional activities

4 - Foreign languages skills

5 - Ability to work on a computer

6 - Skills at specialized applications for professional activities

7 - Having skills in gathering, processing, analyzing, summarizing information and presenting results.

8 - Main technological processes of professional activity skills

9 - Awareness of the legislative and regulatory framework in professional activities

10 - Having related knowledge and skills (not in the main direction of professional activity)
11 - Having skills of interpersonal communication

12 - Ability to work in a team

13 - Ability to organize their own activities (to determine the purpose and tasks of their own activities, the order of the tasks, etc.)

14 - Ability to take into account corporate interests in labor activities 15 - Ability to search and use new information

16 - Loyalty to management and staff

17 - Ability to cope with new and unpredictable situations

18 - Ability to adequately assess the situation, recognize and take into account most of the external and internal factors

19 - Ability to take initiative in professional activities

20 - Creative potential (ability to innovate)

21 - Discipline

22 - Leadership skills

Fig. Matrix of employer's balanced requirements for graduates and available competency characteristics 
factor, that is, they are not key and their current level almost satisfies the needs of employers, includes: leadership qualities, the level of importance of which is the lowest among all indicators and is 4.29 points. At the same time, the satisfaction index remains fairly high $Q_{i}=-0.79$. This suggests that most employers do not see young leaders and consider this staff only as professional executives.

The most problematic and widespread criterion found in it, when assessing the level of competitiveness of graduates from, is Quadrant 3: it included thirteen of the twenty two competencies that were identified for analysis. These data need to be improved as soon as they are, according to employers, key to work and have the lowest quality factor today. The third quadrant got the following qualitative characteristics of the students:

1) foreign language skills are almost at the intersection of the first and third quadrants, it suggests, on the one hand, the high importance of this criterion and the almost satisfactory character of the quality of skills. It should be noted that this criterion was chosen as one of the greatest advantages of the modern young workforce. The significance of the criterion is equal to 4.51 points, ranked second among the general ranking and the sixth place by the coefficient of quality $\left(Q_{i}=-0.86\right)$;

2) ability to search and use new information is one of the key characteristics of the staff in the modern world of active development of information society. This is confirmed by the data obtained by the assessment of its importance in the professional activities by employers (4.41). The difference between a realistic estimate of its level and ideal (coefficient of quality) is -0.89 ;

3) knowing of specialized programs for use in professional activities is characterized by an average degree of importance (4.37 points) and has a coefficient of quality $Q_{i}=-0.9$, which is controversial in terms of comparing its criticality with the indicator of skills of the PC. It suggests that it is relevant to deepen existing knowledge by specialized training;

4) knowing of the legislative and regulatory framework for the organization of professional activities: knowledge of the bases of labor, administrative and economic law. The employers felt the presence of legal knowledge among graduates was very important and desirable during the survey (importance of 4.34). Existing educational programs today include legal disciplines providing basic knowledge on labor and economic legislation, but surveys have shown that the quality of this knowledge is very low (the lowest quality indicator among all the components) $\left(Q_{i}=-1.15\right)$;

5) the ability to organize their activities as a component of collective activity: one of the key socio-personal competencies that is formed at the stage of secondary and vocational education providing effective teamwork. However, the existing educational system is not able to provide a sufficient level of this competence, this is confirmed by the low value of the coefficient of quality $Q_{i}=-0.96$ at an indicator of 4.39 out of 5;

6) the ability to take into account corporate interests in the labor activity: ranks third among twenty two criteria for the degree of importance for employers with an importance indicator of 4.5 , which is quite objective, because the management of the company wants loyal employees. But according to the definition of employers, the degree of formation of this competence among graduates is too low, dissatisfaction with its quality is -1.12 (twentieth place in the satisfaction rating);

7) the availability of practical skills: is one of the competitive advantages of professionals who have sufficient work experience in the specialty, which enables them to engage in work without additional training and retraining (indicator of significance 4.36) and wish, that the level of his representation in young specialists was rather high. However, the modern system is not able to provide a sufficient level of development of this skill due to the specificity and the more theoretical orientation of the Ukrainian education system, therefore, the quality factor for this criterion is very low $(-1.08)$;
8) general theoretical training by the profile (the main task of the education system). But today it is not able to perform it at the proper level. The coefficient of the theoretical training of graduates is equal to -1.06 ;

9) the ability to work in the team is the sixth place among the characteristics, the level of development which does not meet the requirements of employers (quality factor $Q_{i}=-1.05$ ). In addition, it is characteristic and of high importance (4.4 points), which emphasizes the criticality of the state of this indicator and requires prompt action to improve it;

10) skills of processing, analysis and presentation of information is a competence that characterizes the professional level of a specialist in terms of assessing the possibilities of using ones' knowledge. This competence gained an average indicator of importance and an average quality indicator that is not critical, but still submits them to a group of critical and needy revisions;

11) communication skills are not a positive feature of modern youth, which complicates the processes of building interaction in the organization of the production process, both between the leader and subordinates, and among colleagues. The quality of this indicator is at -0.99 , and the importance of 4.36 points out of 5 .

Quadrant 4, the indicators having the least important level, but having critical performance indicators by employers, included: the ability to cope with new and unpredictable situations, the low level of importance of which (4.25 points) indicates the sustainability of production processes and tasks that may arise in the professional activity of a young specialist, and the low level of quality - the lack of ability to develop these skills within the educational system and life $\left(Q_{i}=-0.98\right)$; possession of related knowledge and skills, ranks twenty-first by the importance level -4.28 points and the ninth place in terms of quality $\left(Q_{i}=-0.92\right)$.

Conclusions. The analysis revealed high level of dissatisfaction of employers with the level of qualitative characteristics of graduates. Young professionals are not able to compete freely at the job market for decent jobs, so they cannot completely replace the redundant workforce. The main reasons for the current situation are the critical importance of the quality of practical training of graduates and a complex of social and personal competences, which suggests the need to strengthen these components of educational activity. Employers see opportunities to increase the level of competence of graduates, through the following ways: more than $63 \%$ of respondents indicate the effectiveness of introducing the practice of using teachers with practical experience; almost $40 \%$ note the need to expand the methods of practical training, including those directly at production site; the fourth part emphasizes the necessity of introducing the practice of forecasting the needs of the labor, not only quantitatively, but also in qualitative terms.

Acknowledgements. The research was supported by the Czech non-governmental organization "People in Need" within the framework of "Ukraine Confidence Building Initiative" (UCBI II) project, funded by the United States Agency for International Development (USAID).

\section{References.}

1. Osvita.ua (2018). Universities Ranking “TOP-200 Ukraine» for 2018 year Retrieved from http://osvita.ua/vnz/rating/60985/

2. Higher education (2018). The Network of Higher Education Institutions at the beginning of 2017-2018 academic year. Retrieved from http://vnz.org.ua/statti/10477-merezha-vyschyhnavchalnyh-zakladivna-pochatok-2017-2018-navchalnogoroku

3. Higher education (2018). Displaced HEI: three years at new place. Retrieved from http://vnz.org.ua/statti/10477-merezha-vyschyh-navchalnyh-zakladivna-pochatok-2017-2018navchalnogo-roku

4. Valero, A., \& Van Reenen, J. (2019). The economic impact of universities: Evidence from across the globe. Economics of 
Education Review, 68, 53-67. DOI: 10.1016/j.econedurev. 2018.09.001.

5. Barbara, J., \& Walsh, L. (2018). Realising the Potential of Universities as Significant Development Actors in Post-conflict Societies: A Case Study of the Solomon Islands National University. Forum for Development Studies, 45(1), 47-69. DOI: 10.1080/08039410.2017.1366362.

6. Santos, C. J., Solano, J., \& Nieves, S. (2018). The Academy Against The Post-Conflict And Peace. Case Study. Revista de Comunicación 'Vivat Academia', 143, 135-158. DOI: 10.15178/ va.2018.143.135-160.

7. Pysar, N., Dergachova, V., Kyvliuk, O., \& Svyrydenko, D. (2018). Strategies for development of Ukrainian energy market under conditions of geopolitical challenges. Naukovyi Visnyk Natsionalnoho Hirnychoho Universytetu, 5, 148-154. DOI: 10.29202/nvngu/2018-5/20.

8. Wach, K., Głodowska, A., \& Maciejewski, M. (2018). Entrepreneurial Orientation, Knowledge Utilization and Internationalization of Firms. Sustainability, 10(12): 4711. DOI: 10.3390/su10124711.

9. Wach, K., \& Wojciechowski, L. (2016). Entrepreneurial Intentions of Students in Poland in the View of Ajzen's Theory of Planned Behaviour. Entrepreneurial Business and Economics Review, 4(1), 83-94. DOI: 10.15678/EBER.2016.040106.

10. Rudenko, S., Bazaluk, O., Tsvykh, V., \& Kalmuk, I. (2019). The Role of Philosophical Disciplines in Educational Strategies for Specialist Training in the Field of Public Administration. Naukovyi Visnyk Natsionalnoho Hirnychoho Universytetu. 3, 158-163. DOI: 10.29202/nvngu/2019-3/22.

11. Bazaluk, O. (2018). The Feature Transformations of the Basic Meanings of Greek Paideia in the Educational Theories in the Middle Ages. Schole, 12(1), 243-258. DOI: 10.21267/ AQUILO.2018.12.10428.

12. Możgin, W. (2019). The Condition of a Modern University - Is There a Problem? Future Human Image, 11, 56-65. DOI: $10.29202 / \mathrm{fhi} / 11 / 6$.

13. Kyvliuk, O., Polishchuk, O., Svyrydenko, D., \& Yatsenko, O. (2018) Educational management as education diplomacy: strategies for Ukraine. Naukovyi Visnyk Natsionalnoho Hirnychoho Universytetu, 3, 139-144. DOI: 10.29202/nvn$\mathrm{gu} / 2018-3 / 23$.

14. Oleksiyenko, A. (2019). Why Is Governance Research Important for University Reforms in Ukraine? Ukrainian Policymaker, 4, 27-35. DOI: 10.29202/up/4/5.

15. CISID (2018). Evaluation of Donbas Universities Economic Potential. A summary of the project. Retrieved from http://cisid. org.ua/analitychna-robota/

\section{Оцінка економічного потенціалу університетів Донбасу: проблеми підготовки кадрів і безробіття}

\section{С. Терепищийㅁ, Д. Свириденко ${ }^{1}$, К. Захаренко ${ }^{1}$,} К. Безгін ${ }^{2}$, О. Кульга ${ }^{3}$

1 - Національний педагогічний університет імені М.П.Драгоманова, м. Київ, Україна, e-mail:terepyshchyi@ gmail.com; denis_sviridenko@ukr.net; kzakharenko@ukr.net 2 - Донецький національний університет імені В. Стуса МОН України, м. Вінниця, Україна, e-mail: bezgink@ gmail.com

3 - Таврійський національний університет імені В. І. Вернадського, м. Київ, Україна, е-mail: aa.kulga@gmail.com

Мета. Дослідження спрямоване на оцінку рівня задоволеності роботодавців Донбасу існуючою системою підготовки кадрів та на концептуалізацію набору якостей, якими повинен володіти випускник задля безперешкодної вільної конкуренції на ринку праці в гірничорудному регіоні.
Методика. Кількісне дослідження передбачало проведення електронного соціологічного опитування двох груп респондентів - роботодавців і студентів випускних курсів університетів регіону. Опитуванням були охоплені підприємства, що знаходяться в усіх підконтрольних містах Донецької та Луганської областей. Усього опитуванням були охоплені 93 підприємства. Авторами використана адаптована маркетингова методика ServQual, за якою роботодавець повинен був визначити за компетентнісними критеріями блоки оцінки. Основною метою опитування студентів-випускників виступила оцінка: ефективності реалізації існуючої системи вищої освіти регіону та рівня задоволеності їх освітніх і професійних очікувань. Загальний обсяг опитаних -961 особа.

Результати. Проведене дослідження надало можливість визначити основні наявні проблеми у сфері підготовки кадрів в університетах регіону, оцінити рівень задоволеності роботодавців і студентів якістю набутих знань, умінь і навичок, визначити найбільш критичні компетенції, що $є$ найменш розвиненими у випускників. У результаті роботи оцінені наявний стан та перспективи розширення співпраці між бізнесом і закладами освіти, ефективність діяльності центрів кар'єри в університетах і рівень додаткових послуг, що надають університети у сфері працевлаштування.

Наукова новизна. Уперше сформовано перелік концептуальних рекомендацій щодо підвищення економічного потенціалу 3ВО Донбасу, зокрема через поліпшення механізмів працевлаштування випускників. Виявлена розбіжність уявлень освітніх закладів регіону щодо результатів власної діяльності та існуючих потреб, що представлені у специфічній комбінації знань, умінь і навичок, очікуваних регіональними роботодавцями. Ці розходження, що зафіксовані в комплексному дослідженні основних стейкхолдерів освітянського процесу в регіоні, є наслідком, з одного боку, низької адаптаційної можливості ЗВО, що зумовлено існуючими нормативами, жорстко регламентуючими діяльність університетів, а з іншого, ригідністю ЗВО до процедур реінжинірингу й постійного самовдосконалення власної діяльності.

Практична значимість. Показані шляхи корекції компетентнісного профілю ЗВО гірничорудного регіону на основі більш гнучких навчальних планів, що підлаштовуються під потреби реального сектору економіки регіону. Орієнтовна структура подібних планів повинна складатися із двох компонентів: стабільного ядра та гнучкої (варіативної) периферії. Це дозволить наповнювати додатковою цінністю пропоновані освітні послуги, що орієнтовані на кастомізацію й диверсифікацію.

Ключові слова: економічний потенціал, підготовка кадрів, безробіття, Донбас, гірничорудний регіон, сучасний університет

\section{Оценка экономического потенциала университетов Донбасса: проблемы подготовки кадров и безработицы}

\author{
С. Терепищий느, Д. Свириденко ${ }^{1}$, K. Захаренко ${ }^{1}$, \\ К. Безгин ${ }^{2}$ О. Кульга
}

1 - Национальный педагогический университет имени М. П.Драгоманова, г. Киев, Украина, e-mail:terepyshchyi@ gmail.com; denis_sviridenko@ukr.net; kzakharenko@ukr.net 2 - Донецкий национальный университет имени В. Стуca МОН Украины, г. Винница, Украина, e-mail: bezgink@ gmail.com

3 - Таврический национальный университет имени В.И. Вернадского, г. Киев, Украина, e-mail: aa.kulga@ gmail.com 
Цель. Исследование направлено на оценку уровня удовлетворенности работодателей Донбасса существующей системой подготовки кадров и на концептуализацию набора качеств, которыми должен обладать выпускник для беспрепятственной свободной конкуренции на рынке труда в горнорудном регионе.

Методика. Количественное исследование предусматривало проведение электронного социологического опроса двух групп респондентов - работодателей и студентов выпускных курсов университетов региона. Опросом были охвачены предприятия, находящиеся во всех подконтрольных городах Донецкой и Луганской областей. Всего опросом было охвачено 93 предприятия. Авторами использована адаптированная маркетинговая методика ServQual, по которой работодатель должен был определить по компетентностным критериям блоки оценок. Основной целью опроса студентов-выпускников выступила оценка: эффективности реализации системы высшего образования региона и уровня удовлетворенности их образовательных и профессиональных ожиданий. Общий объем опрошенных - 961 человек.

Результаты. Проведенное исследование позволило определить основные существующие проблемы в сфере подготовки кадров в университетах региона, оценить уровень удовлетворенности работодателей и студентов качеством приобретенных знаний, умений и навыков, определить наиболее критические компетенции, которые являются наименее развитыми у выпускников. В результате работы оценены существующее положение и перспективы расширения сотрудничества между бизнесом и учебными заведениями, эффективность деятельности центров карьеры в университетах и уровень дополнительных услуг, оказываемых университетами в сфере трудоустройства
Научная новизна. Впервые сформирован перечень концептуальных рекомендаций по повышению экономического потенциала ВУЗов Донбасса, в частности через улучшение механизмов трудоустройства выпускников. Выявлено расхождение представлений образовательных учреждений региона о результатах своей деятельности и существующих потребностей, которые представлены в специфической комбинации знаний, умений и навыков, ожидаемых региональными работодателями. Эти расхождения, зафиксированные в комплексном исследовании основных стейкхолдеров образовательного процесса в регионе, является следствием, с одной стороны, низкой адаптационной возможности ВУЗов, что обусловлено существующими нормативами, жестко регламентирующими деятельность университетов, а с другой, ригидностью ВУЗов к процедурам реинжиниринга и постоянного самосовершенствования своей деятельности.

Практическая значимость. Показаны пути коррекции компетентностного профиля ВУЗа горнорудного региона на основе более гибких учебных планов, которые подстраиваются под потребности реального сектора экономики региона. Примерная структура подобных планов должна состоять из двух компонентов: стабильного ядра и гибкой (вариативной) периферии. Это позволит наполнять дополнительной ценностью предлагаемые образовательные услуги, ориентированные на кастомизацию и диверсификацию.

Ключевые слова: экономический потенииал, подготов-

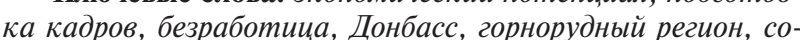
временный университет

Рекомендовано до публікації докт. екон. наук В. П. Кукобою. Дата надходження рукопису 27.11.18. 